\title{
La memoria involuntaria: Marcel Proust y el descubrimiento poético del interior. Un análisis desde la perspectiva filosófica de Walter Benjamin
}

\author{
Maria Llorens \\ Universitat Pompeu Fabra/Universidad de las Artes del Ecuador
}

Resumen: En este artículo abordamos, desde una aproximación al trabajo filosófico de Walter Benjamin, el fenómeno de la memoria involuntaria descubierto por Marcel Proust en el proceso de escritura -ejercicio de subjetivación- de En busca del tiempo perdido (1908-1922). En el análisis se desarrollan las siguientes aproximaciones: la relación entre olvido y memoria (a partir de Sigmund Freud, Henri Bergson y Charles Baudelaire), el descubrimiento poético de la memoria involuntaria (en relación con las cualidades de la iluminación profana), las condiciones para la revelación de las imágenes mnémicas -imágenes del interior- (los antecedentes antiguos y medievales y los contemporáneos surrealistas), la recuperación del tiempo perdido y de la narración en la novela, y el carácter aurático de las imágenes de la memoria involuntaria.

Palabras clave: memoria involuntaria; imágenes mnémicas; iluminación profana; experiencia; aura

\begin{abstract}
Involuntary Memory: Marcel Proust and the Poetic Discovery of the Inner Self. An Analysis from the Philosophical Perspective of Walter Benjamin". In this article, we undertake, from the perspective of Walter Benjamin's philosophical work, the phenomenon of involuntary memory discovered by Marcel Proust in the writing process -exercise of subjectification- of In Search of Lost Time (1908-1922). In the analysis the following approaches are developed: the relation between oblivion and memory (from Sigmund Freud, Henri Bergson and Charles Baudelaire), the poetic discovery of involuntary memory (in relation to the qualities of profane illumination), the conditions for the revelation of mnemic images -images of the inner world- (the ancient and medieval predecessors and the surrealist contemporaries), the recovery of the lost time and of the narration in the novel, and the auratic character of the involuntary memory's images.
\end{abstract}

Keywords: involuntary memory; mnemic images; profane illumination; experience; aura 


\section{En busca del tiempo perdido: experiencia, olvido y memoria}

En un ejercicio de subjetivación mediante la escritura, Marcel Proust descubrió un tipo de memoria que no puede evocarse a voluntad y que escapa al dominio de la inteligencia: la memoria involuntaria. No era la primera vez que un artista formulaba un concepto con la potencia necesaria para encender indagaciones en múltiples campos culturales e intelectuales. Charles Baudelaire, entre la poesía y las reflexiones críticas sobre su tiempo, había conjurado -entre 1859 y 1860- la idea de Modernité1, "lo transitorio, lo fugaz, lo contingente, cuya otra mitad es lo eterno e inmutable"2. A principios del siglo XX, entrando en la crisis de la modernidad ${ }^{3}$, artistas e intelectuales como Marcel Proust y Walter Benjamin repensaron las formas de entender la historia y la memoria,

1 En El pintor de la vida moderna (1863), Charles Baudelaire afirma en relación con el fenómeno de la Modernidad que "se trata, en su caso, de rescatar de lo histórico cuanto la moda contenga de poético, de extraer lo eterno de lo transitorio" (Baudelaire, Ch., El pintor de la vida moderna, Buenos Aires: Taurus, 2014, p. 21).

2 Baudelaire, Ch., El pintor de la vida moderna, p. 22.

3 Pensamos en una crisis de la modernidad intimamente ligada a la Primera Guerra Mundial, que expresa sus contradicciones políticas y económicas derrumbando el optimismo que había embriagado a las sociedades decimonónicas. El mito del progreso -que Walter Benjamin contribuyó a cuestionar- se podía confrontar con la brutalidad de la propia cultura (Benjamin, en Sobre el concepto de historia (1940), plantea la relación dialéctica entre cultura y barbarie). La confianza en la tecnología moderna, el desarrollo capitalista y la consolidación de los regímenes liberales como portadores del progreso, se derrumbó ante la barbarie de la guerra total (Hobsbawm, E. Historia del siglo XX, Buenos Aires: Crítica, 1998). El carácter total de la guerra estuvo dado por formas de violencia que se extendieron más allá del campo de batalla: los ataques aéreos a las poblaciones civiles, el hambre, las violaciones, los saqueos. En 1933, Walter Benjamin planteó la existencia, tras la Gran Guerra, de una pobreza de experiencia, consecuencia del shock de la guerra: "Una generación que había ido a la escuela en tranvía tirado por caballos, se encontró indefensa en un paisaje en el que todo menos las nubes había cambiado, y en cuyo centro, en un campo de fuerzas de explosiones y corrientes destructoras estaba el mínimo, quebradizo cuerpo humano (Benjamin, W., "Experiencia y pobreza", en: Discursos interrumpidos I. Filosofia del arte y la literatura, Buenos Aires: Taurus, 1989, p. 168). El historiador Eric Hobsbawm, al finalizar el siglo, decía: "La humanidad sobrevivió, pero el gran edificio de la civilización decimonónica se derrumbó entre las llamas de la guerra al hundirse los pilares que lo sustentaban" (Hobsbawn, E., o.c., p. 30). Tras la guerra tuvo lugar la brutalización de la politica, que se expresó en la crisis de las democracias liberales y el ascenso de los fascismos: "La experiencia contribuyó a brutalizar la guerra y la política, pues si en la guerra no importaban la pérdida de vidas humanas y otros costes, ¿por qué debían importar en la política? Al terminar la primera guerra mundial, la mayor parte de los que habian participado en ella -en su inmensa mayoría como reclutados forzososodiaban sinceramente la guerra. Sin embargo, algunos veteranos que habian vivido la experiencia de la muerte y el valor sin rebelarse contra la guerra desarrollaron un sentimiento de indomable superioridad, especialmente con respecto a las mujeres y a los que no habian luchado, que definiría la actitud de los grupos ultraderechistas de posguerra" (ibid., p. 34). 
socavando la concepción lineal y homogénea del tiempo (hegemónica en el siglo XIX). Michael Löwy, en la lectura que realiza de las tesis "Sobre el concepto de historia" de Walter Benjamin, cita a Jeanne-Marie Gagnebin, quien se refiere a la coincidencia del intelectual judío-alemán y Proust en la concepción de una historia "abierta" . En Benjamin, la historia permanece abierta por la naturaleza heterogénea del tiempo: en este ocurren "saltos dialécticos", rememoraciones y actualizaciones del pasado y presencias de distintas temporalidades en el presente. Desde la perspectiva benjaminiana, el tiempo es "impuro" porque se encuentra cargado de memoria y actualidad. También se presenta de esta manera en el ejercicio escritural de Marcel Proust: desde una actualidad crítica, el escritor inicia una búsqueda del "tiempo perdido", de lo que se encuentra olvidado en una interioridad temporal.

Sigmund Freud, en Psicopatología de la vida cotidiana (1901), planteó que las "equivocaciones del recuerdo" (olvidos y recuerdos encubridores) no son simples "infidelidades de la memoria" 5 . Más bien parecería existir una contradicción entre memoria (en tanto huella) y recuerdo (en tanto construcción) ${ }^{6}$ : "intensos poderes de la vida posterior han modelado la capacidad de recordar las vivencias infantiles, probablemente los mismos poderes en virtud de los cuales todos nosotros nos hemos enajenado tanto de la posibilidad de inteligir nuestra niñez"7.

En las reflexiones benjaminianas sobre la relación entre experiencia y memoria, entra la lectura de Matière et mémoire (1896), obra de Henri Bergson que permite pensar, sostiene Benjamin, en "una experiencia formada... menos con acontecimientos individuales, fijados propiamente en el recuerdo, que con datos que se han acumulado y que son con frecuencia no conscientes" 8 . Henri Bergson planteaba que "lo que desde nuestra primera infancia hemos sentido,

\footnotetext{
4 Ambos, dice Gagnebin, estaban "preocupados por salvar el pasado en el presente, gracias a la percepción de una semejanza que los transforma: transforma el pasado porque éste adopta una nueva forma, que habría podido desaparecer en el olvido; transforma el presente porque éste se revela como el cumplimiento posible de esa promesa anterior" (Gagnebin, J.W., "W. Benjamin ou a história aberta", en: Benjamin, W., Obras Escolhidas, I, San Pablo: Brasiliense, 1985, p. 16, citado en: Löwy, M., Walter Benjamin: aviso de incendio. Una lectura de las tesis Sobre el concepto de historia. Buenos Aires: Fondo de Cultura Económica, 2012).

5 Freud, S., Obras completas. VI. Psicopatologia de la vida cotidiana, Buenos Aires: Amorrortu, 2012, p. 51.

6 "de esos recuerdos de infancia que se llaman los más tempranos no poseemos la huella mnémica real y efectiva, sino una elaboración posterior a ella" (Freud, S., Obras completas. VI. Psicopatología de la vida cotidiana, p. 52).

7 Ibid., p. 51.

8 Benjamin, W., Baudelaire, Madrid: Abada, 2014, p. 156.
} 
pensado, querido, está ahí, inclinado sobre el presente con el que va a reunirse, presionando contra la puerta de la consciencia, que quería dejarlo afuera" En "Sobre algunos motivos en Baudelaire" (1939), uno de los textos que mejor condensan su pensamiento dialéctico y en constelación, Benjamin aborda el problema de la experiencia en la modernidad vinculándolo al fenómeno de la memoria involuntaria. Los dos escritores que hemos relacionado al comienzo de este apartado, Baudelaire y Proust, aparecen entrelazados en las investigaciones de Benjamin que dan origen a las reflexiones de 1939. La obra de Proust "tiene especial afinidad respecto de la obra de Baudelaire, que reuniendo los días de la reminiscencia ha conformado un año de espíritu"10. En Les fleurs du mal (1857), Proust -lector profundo de Baudelaire- encuentra al tiempo "desintegrado de manera extraña; solo se abre unos pocos días, pero estos son siempre significativos"11. Esos dias especiales son los del tiempo pleno: tiempo de la experiencia -que sufre su declive en la modernité-y de la memoria, ya que "lo que convierte en grandes e importantes los dias festivos es sin duda el encuentro con una vida anterior"12.

\section{El descubrimiento poético de la memoria involuntaria}

De Combray -escenario imaginario y mítico creado por Proust para representar a la pequeña localidad francesa de Illiers en la que vivió su infancia- solo

\footnotetext{
9 Bergson, H., Memoria y vida, Madrid: Alianza Editorial, 1977, p. 48.

10 Benjamin, W., Baudelaire, p. 194.

11 Proust en Benjamin, W., Baudelaire, p. 188.

12 Ibid., p. 191. Benjamin se refiere a un poema de Baudelaire, "La vida anterior", que pertenece a Las flores del mal (Baudelaire, Ch., Poesía completa, Barcelona: Ediciones 29, 1999). De Baudelaire, Benjamin toma la idea de las correspondencias, que le permite acercarse a la noción de tiempo y memoria en Proust. "Correspondencias" es también -además de un concepto- el título de un poema de Baudelaire al que Benjamin se remite en el apartado X de "Sobre algunos motivos en Baudelaire" (Baudelaire, 2014). En el poema, Benjamin encuentra la condensación de una idea de experiencia que "encierra en sí elementos cúlticos" (Baudelaire, p. 189), podriamos decir -adelantándonos el último apartado de este artículo- auráticos. Reproducimos aquí el poema: "La naturaleza es un templo donde vivos pilares / dejan salir a veces sus confusas palabras; / por allí pasa el hombre, por los bosques de símbolos / que lo observan con miradas familiares. / Igual que largos ecos que, lejos, se confunden / en una tenebrosa y profunda unidad, / vasta como la noche y la claridad, / los perfumes, colores y sonidos se responden" (Baudelaire en Benjamin, W., Baudelaire, p. 189). Relaciones de distancia-cercanía y pérdida-aparición se presentan entre el poeta, los objetos, las sensaciones y el lenguaje. Estas relaciones marcan un tipo de experiencia en relación con la memoria: la reminiscencia o -acudiendo al poema que da origen al concepto que en esta nota estamos contextualizando- el encuentro con una vida anterior. Para Benjamin, las correspondencias "son esas fechas que pertenecen a la reminiscencia", "son fechas de la prehistoria" (Baudelaire, p. 190), espacios temporales para la experiencia de restauración de lo olvidado o perdido: una visita a la prehistoria personal.
} 
se destacaba, en la memoria sensible del narrador, en el momento en que esperaba el beso nocturno de su madre, "como si Combray consistiera tan solo en dos pisos unidos por una estrecha escalera, y en una hora única: las siete de la tarde"13. Esto le interesó especialmente a Walter Benjamin, quien, además, parece coincidir con Proust (consciente o inconscientemente, voluntaria o involuntariamente) en la escritura de un breve texto sobre su infancia en Berlín, publicado en 1933: "Mañana de invierno". Allí, Benjamin narra: "El hada, gracias a la cual se puede disponer de un deseo, existe para cada quien, pero son pocos los que saben recordar el deseo que han formulado, y pocos, por eso, los que más adelante, en su propia vida, reconocen su realización. Yo, en cambio, me acuerdo bien del deseo que se me cumplió, y no quiero decir que haya sido más prudente que los deseos de los niños de los cuentos de hadas. Se formaba en mí con la lámpara cuando, muy temprano en la mañana de invierno, a las siete y media, ella se acercaba a mi cama y proyectaba en el techo la sombra de la criada. En la estufa, encendía el fuego... Y alli, muy cerca de mí, más pequeño que yo, algo verdaderamente grave comenzaba a cumplirse y obligaba a la criada a agacharse más de lo que se habría agachado por mí. Cuando el fuego estaba listo, ella metía una manzana a cocerse en el horno... Entonces, me armaba de paciencia hasta que creía oler el perfume espumoso que provenía de una célula del día de invierno aún más profunda y más sorda que el perfume del árbol en la noche de Navidad. Alli estaba el fruto oscuro y caliente, la manzana, que, familiar y pese a ello cambiada como un amigo tras un largo viaje, parecía reencontrarme. En el viaje a través del sombrío país del calor de la estufa, ella había obtenido los aromas de todas las cosas que la jornada me reservaba"14.

El deseo está presente en las dos narraciones, engendrado siempre en la habitación como espacio íntimo y mágico: uno es concedido por el hada -que parece inspirar, misteriosamente, a la criada, al fuego y a la manzana en un despliegue casi animista-; el otro, por la madre que semejante al hada tiene -en el relato de Proust- una presencia distante y un acercamiento al hijo que solo se produce en un momento específico, brindando con el beso un amor cuidadosamente limitado, como la manzana que ofrecía a Benjamin aromas que se hacian esperar y que anticipaban -suavemente, espectralmente- lo que la jornada le reservaba.

El deseo de Benjamin tenía lugar a la mañana (siempre a las siete y media), como una preparación para vivir el día fuera de la casa, en la escuela,

13 Ibid., p.44.

14 Benjamin, W., Escritos franceses, Buenos Aires: Amorrortu, 2012, pp. 79-81. 
lejos de la calidez de la habitación. En cambio, el de Proust se realizaba al final (a las siete de la tarde), como corolario de una espera que ocupaba el tiempo vacío y homogéneo del día. Las dos experiencias infantiles tienen lugar en un momento especial de la jornada, que se repite casi con certeza día tras día. Pero Proust se detiene en otra experiencia, una que no se reitera y que resulta extraordinaria. Es la experiencia del despertar de la memoria involuntaria, que ocurre un día de invierno -como en el relato de Benjamin-, cuando la madre le ofrece un té y una magdalena que, como la manzana de Benjamin, despiertan sensaciones potentes: ya no prepararse para el futuro inmediato, sino comenzar a recuperar el tiempo perdido. Así se condensa, en la narración, esta experiencia que involucra los sentidos, la memoria sensible y un despertar poético-intelectual: "Hacía ya muchos años que no existía para mí de Combray más que el escenario y el drama del momento de acostarme, cuando un día de invierno, al volver a casa, mi madre, viendo que yo tenía frío, me propuso que tomara, en contra de mi costumbre, una taza de té. Primero dije que no; pero luego, sin saber por qué, volví de mi acuerdo. Mandó mi madre por uno de esos bollos, cortos y abultados, que llaman magdalenas, que parece que tienen por molde una valva de concha de peregrino. Y muy pronto, abrumado por el triste día que había pasado y por la perspectiva de otro tan melancólico por venir, me llevé a los labios unas cucharadas de té en el que había echado un trozo de magdalena. Pero en el mismo instante en que aquel trago, con las migas del bollo, tocó mi paladar, me estremecí, fija mi atención en algo extraordinario que ocurría en mi interior. Un placer delicioso me invadió, me aisló, sin noción de lo que lo causaba. Y él me convirtió las vicisitudes de la vida en indiferentes, sus desastres en inofensivos y su brevedad en ilusoria, todo del mismo modo que opera el amor, llenándose de una esencia preciosa; pero, mejor dicho, esa esencia no es que estuviera en mí, es que era yo mismo. Dejé de sentirme mediocre, contingente y mortal. ¿De dónde podría venirme aquella alegría tan fuerte? Me daba cuenta de que iba unida al sabor del té y del bollo, pero le excedía en mucho y no debía de ser de la misma naturaleza. ¿De dónde venía y qué significaba? ¿Cómo llegar a aprehenderlo? Bebo un segundo trago, que no me dice más que el primero; luego un tercero, que ya me dice un poco menos. Ya es hora de pararse, parece que la virtud del brebaje va aminorándose. Ya se ve claro que la verdad que yo busco no está en él, sino en mi”"15.

\footnotetext{
${ }^{15}$ Proust, M., En busca del tiempo perdido. Por el camino de Swann, Buenos Aires: CS Ediciones, 2006, p. 45.
} 
Como Baudelaire en Las flores del mal, Proust extrae un momento pleno de entre los dias vacíos, homogéneos, invadidos por el spleen que avanza -en el mundo urbano moderno- sobre el terreno de la experiencia, amenazándola de muerte. Se trata de un momento en el que se produce el encuentro con una vida anterior. Este encuentro se da involuntariamente, de manera inesperada. Tiene lugar, además, en las condiciones menos propicias para la experiencia y la reminiscencia: aquellas fundadas en el spleen, mal propio de la Modernité, identificado por Baudelaire en su lucha poético-lírica contra la ingratitud de un público que ya no conoce la concentración. El vacío del tiempo homogéneo, el tedio del eterno retorno de lo siempre igual y la melancolía invaden el espíritu del narrador, hasta que -inesperadamente- ocurre algo extraordinario: "abrumado por el triste día que había pasado y por la perspectiva de otro tan melancólico por venir, me llevé a los labios unas cucharadas de té en el que había echado un trozo de magdalena. Pero en el mismo instante en que aquel trago, con las migas del bollo, tocó mi paladar, me estremecí, fija mi atención en algo extraordinario que ocurría en mi interior"16. Las sensaciones provocadas por el té y la magdalena, a través del olfato y el gusto, habían despertado imágenes mnémicas ${ }^{17}$, presentes de modo latente, inconsciente, inasequibles para la voluntad. El narrador intenta evocar las sensaciones que le había traído la memoria involuntaria, pero fracasa. Abandona estas tentativas y se entrega a los pensamientos más superficiales. De pronto, en plena distracción, las imágenes del pasado emergen: "Y como ese entretenimiento de los japoneses que meten en un cacharro pedacitos de papel, al parecer, informes, que en cuanto se mojan empiezan a estirarse, a tomar forma, a colorearse y distinguirse, convirtiéndose en flores, en casas, en personajes consistentes y cognoscibles, así ahora todas las flores de nuestro jardín y las del parque del señor Swann y las ninfeas del Vivonne y las buenas gentes del pueblo y sus viviendas chiquitas y la iglesia y Combray entero y sus alrededores, todo eso, pueblo y jardines, que va tomando forma y consistencia, sale de mi taza de té"18.

Así se hace cognoscible, mediante la experiencia sensible que despierta una memoria involuntaria-también compuesta por huellas de las sensaciones-, una parte del pasado de ese tiempo perdido hasta entonces que empieza a recuperarse para la conciencia. Se trata de una cognición cercana a la que

\footnotetext{
16 Ibid.

17 Aquí tomamos de Sigmund Freud el concepto de huella mnémica, para pensar en una imagen de ese orden.

18 Proust, M., En busca del tiempo perdido, p. 47.
} 
Walter Benjamin concibió para sus investigaciones en el marco de la Obra de los Pasajes (1927-1940). En el Konvolut N, Benjamin despliega sus ideas para una teoría del conocimiento inspirada en el surrealismo, el marxismo, el romanticismo alemán y la teología judia. El concepto que condensa la potencia de estas influencias heterogéneas es el de iluminación profana. Para Benjamin, existe un "ahora de cognoscibilidad en el que las cosas ponen su verdadero gesto surrealista": es el momento extraordinario de la revelación. En Proust, el tiempo perdido se recupera, se hace cognoscible, empleando las palabras de Benjamin, "a modo de relámpago" y sin mediaciones de la inteligencia. Asî lo asalta la memoria involuntaria, mientras que "el texto es el largo trueno que después retumba", la comprensión a través de la escritura. Así, dice Benjamin, "en Proust es importante que la vida entera se vuelque en el punto de fractura de la vida, dialéctico en grado máximo en el despertar"19.

A partir de aquí, proponemos pensar la floración de la memoria involuntaria como un descubrimiento poético del interior: "captar firmemente lo que ha sido" -el tiempo perdido en Proust- "como una imagen que relampaguea en el ahora de la cognoscibilidad"20. Entendemos que el descubrimiento poético de la memoria involuntaria implica, por un lado, dar con un pasado olvidado -que es actualidad en el interior- a partir de las sensaciones que provoca un objeto, a las que siguen las imágenes como relámpagos que nos revelan -en un momento extraordinario, fuera del dominio de la inteligencia, fuera del spleen-fragmentos del fondo subjetivo. Por otro lado, este descubrimiento es poético en tanto implica creación, un hacer con las imágenes en la literatura, un ejercicio de subjetivación a través de la escritura, un trabajo sobre la propia subjetividad que se exterioriza en primer lugar ante el propio sujeto mediante el acto de escribir. Por último, este descubrimiento, que se funda en las sensaciones que despiertan imágenes mnémicas, implica conocimiento, un hacer sensible e intelectual con el propio interior y con el fenómeno que se descubre en la reflexión, como el trueno que sigue al relámpago, el texto a la imagen, el concepto al hallazgo sensible.

3. Buscar es esperar encontrar: la pasividad y el azar como condiciones para la revelación de la memoria olvidada

En Proust, el descubrimiento poético del interior, que se produce a partir de la floración de imágenes de la memoria involuntaria, enlaza dos actitudes o

\footnotetext{
19 Benjamin, W., El libro de los pasajes, Madrid: Akal, 2013, p. 466.

20 Ibid., p. 475.
} 
dos posiciones del sujeto en relación con el pasado y la memoria: una activa, de búsqueda; y una pasiva, de espera. El ejercicio activo de la memoria -que incluye la escritura como medio de indagación interior- puede entenderse desde el antiguo concepto griego de anamnesis, definido por Paul Ricoeur como rememoración ${ }^{21}$. En ella interviene la inteligencia, la conciencia, la voluntad. En cambio, en la segunda posición, la de la espera, la voluntad se suspende. Se trata de una posición que se correspondería con la mneme: la memoria que emerge para ser recibida, en su fragmentariedad, involuntaria y pasivamente por el sujeto. La mneme es la memoria-pasión, la memoria que le acontece al sujeto. Es la huella-afección $n^{22}$ o, para emplear asociativamente el concepto freudiano, la imagen mnémica ${ }^{23}$.

Freud mediante, Walter Benjamin abordó -en "Sobre algunos motivos en Baudelaire" (1939)- los estudios de Theodor Reik (1888-1969) para pensar la memoria en relación con una experiencia ligada a la dimensión del inconsciente. Pensando en la vivencia moderna del shock, Benjamin se interesó en el concepto de Reik de memoria consciente, aquella que es esencialmente conservadora, que protege al sujeto de las impresiones que pueden provocar un efecto traumático. Benjamin apuntaba la afirmación de Freud de que "los restos del recuerdo son fuertes y firmes si el incidente que los deja atrás no ha llegado a la conciencia"24 y que, entonces, devenir consciente y dejar una huella en la memoria resultan ser procesos incompatibles ${ }^{25}$. "Traduciéndolo al modo de hablar propio de Proust -concluye Benjamin- solo puede convertirse en componente de la mémoire involontaire lo que no ha sido 'vivenciado' con conciencia y explícitamente, es decir, aquello que al sujeto no le sucedió como 'vivencia"26. Lo que de alguna manera Benjamin nos presenta, recogiendo a Freud, Reik y Proust, es que, de un lado, nos encontramos con la dimensión consciente del sujeto, la vivencia y el recuerdo -integrado al tiempo vivido y ordenado secuencialmente a través de la inteligencia-; y, del otro, hallamos la dimensión inconsciente, que es la de la experiencia (en tanto tiempo psicológico, siguiendo a Henri Bergson) y la memoria involuntaria.

Lo que encontramos en la obra de Proust, es que la imagen mnémica, la memoria-pasión, es enfrentada con inteligencia en el descubrimiento poético y

\footnotetext{
${ }^{21}$ Ricoeur, P., La memoria, la historia, el olvido, Buenos Aires: Fondo de Cultura Económica, 2013.

22 Ibid., p. 32.

23 Imagen mnémica-huella mnémica.

24 Benjamin, W., Baudelaire, p. 160.

25 Ibid., p. 159.

26 Ibid., p. 160.
} 
filosófico de la memoria involuntaria. La búsqueda del tiempo perdido se inspira en la rememoración que acontece más allá de la voluntad, en la aparición de imágenes-afecciones, en la revelación del pathos interior.

Paul Ricouer nos recuerda la verdad profunda de la anamnesis griega: "buscar es esperar encontrar"27. Así, se reúnen dos posiciones subjetivas en relación con la memoria: la activa y la pasiva, la voluntad de conocer el pasado experimentado, olvidado, indestructible en el inconsciente, y la espera -en atención flotante- a su manifestación en imágenes, en relámpagos que iluminan la actualidad del sujeto y que dan lugar a la poiesis desde un interior que empieza a ser descubierto.

En la experiencia de Proust, el pasado olvidado y latente se hace cognoscible a partir de sensaciones específicas que activan la memoria sensible manifestándose en imágenes. Un fenómeno semejante, susceptible de ser asociado con el de la memoria involuntaria por la condición de pasividad del sujeto y la manifestación del inconsciente, es evidentemente el fenómeno onírico. En La interpretación de los sueños (1899-1901), Freud comienza su estudio del fenómeno onírico con una exposición de la "bibliografia científica sobre los problemas del sueño"28 en la que destacan los aportes de Hildebrandt, Strümpell, Volkelt, Maury, Binz, entre otros. A partir de entonces Freud se propone demostrar que existe "una técnica psicológica que permite interpretar sueños". En este sentido, busca una comprensión del fenómeno onírico recuperando la antigua intuición filosófica de que los sueños son material para la interpretación. Mientras las teorias con pretensiones científicas consideraban al sueño como un proceso somático, "muy diferente fue la opinión de los profanos en todos los tiempos", quienes se empeñaron en "interpretar el sueño"29.

27 Ricoeur, P., La memoria, la historia, el olvido, p. 556.

28 Freud, S., Obras completas. IV. La interpretación de los sueños, Buenos Aires: Amorrortu, 2012, p. 29.

29 A Freud le interesó la idea de que los sueños ofrecen indicios por ser productos de la actividad anímica del durmiente -asumiendo la noción de Aristóteles, quien se distancia de la tradición que considera los sueños como inspiraciones divinas- (Obras completas. IV. La interpretación de los sueños, p. 31). Otro antecedente relevante, citado por Freud, es Artemidoro Daldiano (siglo II d.c), considerado -en la Antigüedad tardia- como máxima autoridad en la interpretación de sueños. Es entonces que Freud distingue dos métodos antiguos de interpretación de los sueños: el de la interpretación simbólica -sustitución del contenido onírico por otro comprensible y análogo-y el método del descifrado, que trata al sueño como una escritura cifrada para traducir. Este último es el de Artemidoro y el que más le interesa a Freud. Aunque desestima su sustentación, no deja de decir lo siguiente: "me vi llevado a admitir que estamos otra vez frente a uno de esos casos, no raros, en que una creencia popular antiquísima, mantenida con tenacidad, parece aproximarse más a la verdad de las cosas que el juicio de la ciencia que hoy tiene validez" (ibid., p. 121). 
En el sueño se pueden saber y recordar cosas que se sustraen de nuestra capacidad de recuerdo de la vigilia, así como en la irrupción de la memoria involuntaria se nos aparecen imágenes ocultas para el recuerdo ordinario. Por otro lado, la "singular predilección de la memoria onírica por lo indiferente -y en consecuencia inadvertido- en las vivencias diurnas" ${ }^{30}$, se corresponde con el fenómeno de la memoria involuntaria que registra, en lo aparentemente insignificante, una carga anímica, emocional y energética relevante para el sujeto.

La memoria onírica puede ser entendida como una forma de memoria involuntaria-memoria-pasión-, si pensamos en la compartida condición de pasividad del sujeto. La voluntad entra en suspensión, dando lugar a la manifestación de unas imágenes interiores que se presentan con una apariencia de ajenidad, al estar más allá de la conciencia y de la lógica racional. En el estudio sobre las particularidades psicológicas del sueño, Freud explica que, si bien sabemos que el sueño es resultado de nuestra propia actividad psíquica, aparece -al despertar- como "algo ajeno, cuya paternidad nos apuramos tan poco a confesar que (en alemán) tanto decimos Mir hat geträumt (me ha ocurrido un sueño) cuanto Ich habe geträumt (he soñado)"31.

Esta relación de alteridad con el inconsciente, cuyas manifestaciones parecen ser ajenas, genera un extrañamiento en el sujeto con respecto a su propia interioridad profunda y oculta. Aunque en la narración proustiana las imágenes de la memoria involuntaria son reconocidas casi inmediatamente, no dejan de presentarse como fragmentos de una vida anterior. Se trata, siguiendo ahora a Bergson, del tiempo interior, en el que, como explicó Gilles Deleuze en su curso "Cine: imágenes y signos del movimiento" (Universidad de Vincennes, 1982-83), existe un lugar desmesurado, una talla interior. La talla interior de los dias del tiempo pleno (volviendo a la concepción benjaminiana) se abre a través de intervalos-cuerda, como la magdalena y el té en Combray, que elevan uno de los instantes de la vida a la enésima potencia: un instante presente que resucita un instante pasado, confiriéndole una fuerza especial ${ }^{32}$. "Todo pasa -dice Deleuze- como si la cuerda tendida entre dos instantes, el instante presente y el instante pasado, multiplicara el instante pasado a través del instante presente y, desde entonces, como si elevara el instante pasado a una potencia que jamás tuvo"33. Así nos lo narra la voz literaria de Proust: "Siento

\footnotetext{
${ }^{30}$ Freud, S., Obras completas. IV. La interpretación de los sueños, p. 46.

31 Freud, S., Obras completas. IV. La interpretación de los sueños, p. 72.

32 Deleuze, G., Cine II: los signos del movimiento y el tiempo, Buenos Aires: Cactus, 2014, p. 532.

33 Ibid., p. 534.
} 
estremecerse en mí algo que se agita, que quiere elevarse; algo que acaba de perder ancla a una gran profundidad, no sé qué, pero va ascendiendo lentamente; percibo la resistencia y oigo el rumor de las distancias que va atravesando... Indudablemente, lo que así palpita dentro de mi ser será la imagen y el recuerdo visual que, enlazado al sabor aquel, intenta seguirlo hasta llegar a mí. Pero lucha muy lejos, y muy confusamente; apenas si distingo el reflejo neutro en que se confunde el inaprensible torbellino de los colores que se agitan; pero no puedo discernir la forma y pedirle, como el único intérprete posible, que me traduzca el testimonio de su contemporáneo, de su inseparable compañero el sabor, y que me enseñe de qué circunstancia particular y de qué época del pasado de se trata... ¿Llegará hasta la superficie de mi conciencia clara ese recuerdo, ese instante antiguo que la atracción de un instante idéntico ha ido a solicitar tan lejos, a conmover y alzar en el fondo de mi ser?". ${ }^{44}$ Henri Bergson, dice Benjamin, había diagnosticado un antagonismo entre dos modos de vida: la vita activa, imperante en la modernidad, y la vita contemplativa, que es la "vida especial" 35 , la que propicia la apertura del sujeto al reencuentro con una "vida anterior"36. La vía de la contemplación es heredera de la experiencia de subjetivación religiosa, antigua y medieval. También es la vía de Leonardo Da Vinci, quien, como señala Victoria Cirlot, practicaba la contemplación para vislumbrar imágenes que propiciaran la creación artística ${ }^{37}$. La vita contemplativa, que supone la plenitud de la experiencia, la apertura receptiva, la indagación en la profundidad interior y la posibilidad de la iluminación (religiosa o profana), es la vida que -como ya explicamos previamente- se encuentra amenazada en los tiempos de la modernidad.

Sin embargo, mediante la escritura, Proust forjó un espacio para la vita contemplativa. Como los surrealistas, se sirvió de un procedimiento artificial para producir esta experiencia en unas condiciones sociales adversas para la poética que nace del ejercicio con el interior ${ }^{38}$. En este punto, volvemos a la idea de que en el ejercicio de Proust "buscar es esperar encontrar" o, dicho de otra manera, hay una voluntad de construir condiciones objetivas y subjetivas

\footnotetext{
${ }^{34}$ Proust, M., En busca del tiempo perdido. Por el camino de Swann, p. 46.

35 Benjamin, W, Baudelaire, p. 188.

${ }^{36}$ Walter Benjamin toma la expresión "vida anterior" del título de un poema de Charles Baudelaire (Benjamin, W., Escritos franceses, p. 225; Baudelaire, Ch., Poesía completa, p. 63).

37 Cirlot, V., La visión abierta. Del mito del Grial al surrealismo, Madrid: Siruela, 2010, p. 29.

38 Únicamente puede producirse una experiencia semejante, dice Benjamin, "a través de un procedimiento sintético", "porque cada vez menos podremos esperar que surja naturalmente" (Baudelaire, p. 188).
} 
que permitan que lo que está más allá del control de nuestra voluntad pueda descubrirse, devolviéndole al narrador-autor algo propio y muy significativo: la memoria de su experiencia pasada.

Esta memoria es, como advierte Benjamin, automática. Mientras Bergson presenta el "giro hacia la actualización contemplativa del flujo de la vida" como si fuera "producto de una decisión libre"39, Proust convierte la mémoire pure en mémoire involontaire ${ }^{40}$. El autor de En busca del tiempo perdido parte de la filosofia bergsoniana para después despegarse de ella, descubriendo la singularidad del fenómeno del "giro hacia la actualización contemplativa del flujo de la vida"41: la involuntariedad. La misma pasividad que sostiene la experiencia contemplativa opera en la manifestación de las imágenes ocultas en la memoria y determina la forma en la que puede producirse su actualización. La posibilidad de acceder a las imágenes del "tiempo perdido" no depende de una "decisión libre", sino de la suspensión de la voluntad. Solo pueden fluir estas imágenes mediante una momentánea emancipación del sujeto de su propia conciencia. Paradójicamente, para que esto ocurra debe existir una voluntad de búsqueda de condiciones que favorezcan el automatismo.

Benjamin interpreta que, para Proust, "es cuestión de azar si el individuo logra obtener una imagen de sí mismo, si logra apoderarse de su experiencia"42. En el primer libro, Por el camino de Swann, cuando el narrador reflexiona sobre la búsqueda del tiempo perdido y el encuentro de sus fragmentos mediante objetos y sensaciones que activan la memoria sensible, Proust se refiere al azar como una de las condiciones: "Considero muy razonable la creencia céltica de que las almas de los seres perdidos están sufriendo cautiverio en el cuerpo de un ser inferior, un animal, un vegetal o una cosa inanimada; perdidas para nosotros hasta el dia, que para muchos nunca llega, en que suceda que pasamos al lado de un árbol o que entramos en posesión del objeto que les sirve de cárcel. Entonces se estremecen, nos llaman, y en cuanto las reconocemos se rompe el maleficio. Y liberada por nosotros, vencen a la muerte y tornan a vivir en nuestra compañía. Así ocurre con nuestro pasado. Es trabajo perdido querer evocarlo, e inútiles todos los afanes de nuestra inteligencia. Se oculta fuera de sus dominios y de su alcance, en un objeto material (en la sensación que ese objeto material nos daría) que no sospechamos. Y del azar depende

\footnotetext{
39 Ibid.

40 Ibid.

41 Ibid.

42 Ibid., p. 189.
} 
que nos encontremos con ese objeto antes de que nos llegue la muerte, o que no lo encontremos nunca"43.

Depender del azar para dar con el elemento de la realidad material que nos permita asociar, involuntariamente, sensaciones actuales con huellas mnémicas (en un acto de reminiscencia) implica, nuevamente, la pasividad del sujeto. Sin embargo, debemos tener cuidado con asumir una identificación total entre pasividad, azar y fatalidad ${ }^{44}$. En el campo creativo de principios del siglo XX, en el que trabajaron escritores introspectivos como Proust y artistasintelectuales surrealistas como André Breton, podemos entender la pasividad como entrega del sujeto al fluir -a veces perturbador- de su otro interior, el inconsciente. En el terreno surrealista, la pasividad no se corresponde con el destino, sino con el azar, siempre ligado al juego y al deseo. André Breton llamaba azar objetivo a la "extraña mezcla entre lo fortuito y lo necesario", la "coincidencia entre el deseo subjetivo y la realidad exterior"45. Lo que se agita en el propio interior logra manifestarse en la libertad del juego, profanando la concepción trágica de la pasión.

La experiencia de subjetivación que Proust aborda se acerca íntimamente -probablemente sin proponérselo- a la tradición mística medieval, recuperada y profanada ${ }^{46}$ por los surrealistas, quienes supieron encontrar en ella una potencia creativa que, tras la crisis de la modernidad, podía ponerse al servicio del rescate de la imaginación. Victoria Cirlot estudia las experiencias visionarias del siglo XII (en particular la de Hildegard Von Bingen) y las confronta con las del surrealismo de los años veinte del siglo pasado. Encuentra la persistencia y actualización de un modelo visionario que proviene de la Antigüedad tardía

${ }^{43}$ Proust, M., En busca del tiempo perdido. Por el camino de Swann, pp. 44-45.

$44 \mathrm{El}$ azar se presenta como un acontecimiento incontrolable que escapa a la razón en la medida en que ésta solo da cuenta de lo que ocurre regularmente. El azar, explica José Manuel Cuesta Abad, es la causa inconstante, anómala, "irreductiblemente múltiple" ("Futuro del surrealismo", en: Becerra, E. (ed.), El surrealismo y sus derivas: visiones, declives y retornos, Madrid: Abada, 2013, p. 21).

${ }^{45}$ Cirlot, V., La visión abierta. Del mito del Grial al surrealismo, p. 48. Eran las manifestaciones del azar objetivo lo que buscaban estos artistas en la observación de las piedras o las estrellas, superficies elementales que podian activar la imaginación. Victoria Cirlot propone pensar estas tentativas surrealistas como formas de captar el instante del encuentro entre el mundo exterior (perceptible con los sentidos) y el mundo interior (aprehendido a través de los sentidos interiores), alcanzando así el estado sublime (Abel Gance).

${ }^{46}$ Empleamos aquí el concepto de profanación siguiendo la definición a la que llega Giorgio Agamben en el ensayo "Elogio de la profanación". Agamben se remite a los juristas romanos, quienes entendian la consagración como la salida de las cosas de la esfera del derecho humano y la profanación como la restitución de las cosas al libre uso de los hombres (Profanaciones, Buenos Aires: Adriana Hidalgo Editora, 2005, p. 97). 
y que se expresa en el libro del Apocalipsis de Juan de Patmos. Se trata de una experiencia de revelación y escritura, en la que las imágenes que se manifiestan ocupan un lugar central para el conocimiento mediante la iluminación sagrada de lo que "está por venir"47. Estas imágenes son verdaderas porque, como Agustín de Hipona afirmaba en el siglo IV a.C., "vienen de Dios"48. Como las imágenes oníricas que aparentan ser ajenas al durmiente que despierta, las imágenes visionarias provienen de una alteridad que, en este caso, es divina. Las imágenes verdaderas, en el caso del surrealismo -que se apropia de categorías y procedimientos psicoanalíticos-son las que provienen del inconsciente, que de alguna manera se presenta como un otro interno. En ambos casos, las imágenes verdaderas provienen de una instancia que presenta algún tipo de alteridad en relación con el sujeto consciente. Sin embargo, aun en la Edad Media -cuando no se conocía la escisión del sujeto en una conciencia y un inconsciente, y cuando aún la cultura no había transitado la desacralización que trajo la modernidad- se reconocía, en la experiencia visionaria, la importancia del interior del sujeto en la recepción de las imágenes verdaderas (entendidas como imágenes de Dios). En su libro Confesiones (397), San Agustín aborda la experiencia de encuentro y reencuentro con Dios desde el conocimiento del interior mediante la introspección y la escritura. Allí descubre un ojo del alma, que se distingue del ojo de la carne, ya que el primero puede dirigirse hacia el interior profundo y recibir la luz divina. Desde entonces, y así lo asume también Ricardo de San Víctor (siglo XII), se reconocen dos tipos de sentidos: los exteriores -físicos, corporales, que reciben los estímulos del mundo visible y tangible- y los interiores -que pueden captar lo que se encuentra más allá de lo perceptible, es decir, lo sagrado-. Así, cuando Juan de Patmos asume el imperativo de escribir "todo lo visto y oído"49, se refiere -leyéndolo con San Agustín- a todo lo que ha recibido de Dios con sus sentidos interiores: el ojo interior y el oído interior.

Juan, en el libro que integra el Nuevo Testamento y en las miniaturas medievales que representan sus visiones, aparece en una posición de pasividad en relación tanto con las imágenes sagradas que se le revelan como con la escritura. Recibe las imágenes y las palabras divinas y asume el imperativo de transmitir a las siete iglesias de Asia el mensaje que se le ha revelado. Así,

\footnotetext{
47 Juan de Patmos habla de "lo que está por venir" (Apocalipsis 1,1).

48 San Agustín distinguía las imágenes del pensamiento, creadas por los hombres, de las imágenes verdaderas, que eran las de Dios.

49 Apocalipsis 22,8.
} 
se convierte en instrumento de Dios. Además, su experiencia escrita nos habla de la conexión entre la condición de pasividad y otra condición necesaria para la revelación: un tiempo y espacio extraordinarios ${ }^{50}$. Juan dice haber sido "arrebatado en espíritu" 51 cuando estaba desterrado: la visión es algo que le acontece en un momento, "el día del Señor"52, y en un lugar, la isla de Patmos, que son extraordinarios. Volvemos a Benjamin y a la idea del tiempo pleno, tiempo de experiencia y memoria, que tiene lugar en el terreno de lo extraordinario. En el caso de Proust, "los dias especiales" -en los que el sujeto vence la melancolía, el tedio y el vacío, males propios de la modernidad- son aquellos en los que se produce el encuentro con una vida anterior, el descubrimiento poético del interior mediante la floración de imágenes verdaderas arrojadas por la memoria involuntaria.

Tanto la iluminación profana, en la experiencia surrealista y proustiana, como la iluminación religiosa, en la experiencia visionaria medieval, implican la conjunción de lo extraordinario y lo pasivo. André Breton, quien -como plantea Victoria Cirlot- encontraba en el Apocalipsis un paradigma para la imaginación radical, decía en el Manifiesto Surrealista de 1924: "Entrad en el estado más pasivo, o más receptivo, de que seáis capaces"53. Los artistas-intelectuales de las primeras vanguardias (los surrealistas, pero también los dadaístas y los expresionistas en el cine) compartieron ciertos aspectos de la sensibilidad medieval al enfrentarse a lo oculto, enigmático, extraño e inquietante. Se interesaron por las imágenes que "el hombre no evoca, sino que se le ofrecen espontáneamente, despóticamente, sin que las pueda apartar de sî"54. Cuando Max Ernst, como señala Cirlot, sostenía con firmeza que había que entregarse a la espera de las imágenes, asestando un último golpe al mito romántico (y moderno) del genio creador, estaba recuperando -en la plenitud de un tiempo que reúne memoria y actualidad- la tradición medieval del visionario instrumento de lo divino y del artífice-artesano que sigue las reglas del gremio y las convenciones simbólicas

\footnotetext{
${ }^{50}$ Como explica el historiador Jacques Le Goff, lo extraordinario ocupa un lugar central en la cultura, las mentalidades y sensibilidades medievales. Aparece ligado a la experiencia mística, pero también a otros aspectos de la cultura. Le Goff dice que "lo que arrastra la adhesión de los espíritus medievales no es lo que se puede observar y probar mediante una ley natural, mediante un mecanismo regularmente repetido. Al contrario, es lo extraordinario, lo sobrenatural o, en todo caso, lo anormal" (La civilización del Occidente medieval, Barcelona: Paidós, 1999, p. 291).

51 Apocalipsis 1, 10.

52 Ibid.

53 Breton, A., "Manifiesto surrealista", en: Calvo Serraller, F., Marchán Fiz, S. y A. González, Escritos de arte de vanguardia. 1900/1945, Madrid: Istmo/Akal, 2009, p. 401.

54 Ibid, p. 406.
} 
compartidas socialmente, pero que a la vez orienta la praxis mimética según un modelo interior.

\section{Narración y experiencia de la memoria involuntaria}

Antes de comenzar la escritura de En busca del tiempo perdido, Marcel Proust emprendió la tarea de restaurar la figura del narrador ${ }^{55}$. Entre 1908 y 1909, de manera fragmentaria, Proust escribe "Los cuadernos de Sainte-Beuve", denominados así en alusión al crítico literario Charles-Augustin Sainte-Beuve, quien había ignorado a Baudelaire ${ }^{56}$ (poeta fundamental para Proust). En estos cuadernos reflexiona sobre la memoria, poniendo en cuestión el valor absoluto de la inteligencia: "Cada día comprendo mejor que solo fuera de ella puede un escritor recobrar algo de sus impresiones pasadas, es decir, alcanzar algo de sí mismo"57. Proust emprende la experimentación con la narración de situaciones en las que consigue, involuntariamente, descubrir fragmentos de su pasado olvidado, perdido para la conciencia: "La otra tarde había vuelto helado por la nieve y no conseguía entrar en calor, por lo que al ponerme a leer en mi cuarto a la luz de la lámpara, mi vieja cocinera me propuso hacerme una taza de té, que nunca tomo. Y el azar quiso que me trajera algunas rebanadas de pan tostado. Mojé el pan tostado en la taza de té, y en el instante en que me llevé el pan tostado a la boca y lo sentí reblandecerse en el paladar impregnado de aquel sabor a té, sentí una agitación, olores de geranios, de naranjos, una sensación de luz extraordinaria, de felicidad; me quedé inmóvil, temiendo detener con un solo movimiento lo que estaba ocurriendo en mí sin que pudiera comprenderlo, y sin dejar de aferrarme a ese sabor de pan mojado que parecía ser la causa de tantas maravillas, cuando de pronto cedieron las paredes tambaleantes de mi memoria y los veranos que pasaba en la casa de campo de la que he hablado irrumpieron en mi conciencia, con sus mañanas, trayendo consigo la sucesión, la carga incesante de las horas felices" 58 . Solo entonces sobrevino el recuerdo. El pan tostado mojado en el té estaba ligado -escribe Proust-a la "resurrección, en virtud de un pacto mágico que desconocía"59. Los recuerdos renacieron en la conciencia "como esas florecillas japonesas que solo reviven en el agua"60.

\footnotetext{
55 Benjamin, W., Escritos franceses, p. 190.

56 Proust, M., Contra Sainte-Beuve: Recuerdo de una mañana, Madrid: Alianza Editorial, 2016, p. 27.

57 Proust, M. Contra Sainte-Beuve: Recuerdo de una mañana, p. 31.

58 Ibid., p. 32.

59 Ibid., p. 33.

60 Ibid.
} 
Del mismo modo explica otra circunstancia, en Venecia, en la que nuevamente la inteligencia no había podido devolverle fragmentos olvidados de su pasado. Otra vez un objeto -en este caso, el adoquinado- despierta las sensaciones que hacen florecer los recuerdos, a partir de una agitación que se suscita en el interior del sujeto y que le revela "esa sustancia pura de uno mismo que es una impresión pasada... la vida pura conservada en estado puro"61. "Vida pura", impresión que no alcanza a ser manipulada por la consciencia, manteniéndose en "estado puro" fuera del dominio de la inteligencia. Esa vida del pasado, reflexiona el escritor, solo la podemos conocer "conservada", "pues en el momento en que la vivimos no aparece en nuestra memoria, sino rodeada de sensaciones que la suprimen"62. La inteligencia, escribe Proust, no puede provocar las resurrecciones del pasado oculto. Sin embargo, por otro lado, "es a la propia inteligencia a quien hay que pedir que establezca su propia inferioridad"63.

Es desde la propia inteligencia que Proust logra distinguir la memoria voluntaria de la involuntaria, convirtiendo a la segunda en el centro de sus indagaciones filosóficas que se desarrollaron en el trabajo literario que representó En busca del tiempo perdido. No fue el ensayo, entonces, el género que las recogió, sino la novela. Una novela heterodoxa, elaborada siguiendo -probablemente sin pretenderlo- el principio del montaje instalado por el cine y las vanguardias artísticas que hicieron del collage una forma creativa de asumir un arte inorgánico, compuesto por fragmentos. El narrador, en El tiempo recobrado -último volumen de la obra- decía que trabajaría como Françoise (la mujer que realizaba las tareas domésticas en la casa de su familia), construyendo su libro "pura y simplemente como un vestido"64. Entonces, "al tiempo que me señalara mis cuadernos roídos, como la madera en la que se ha introducido un insecto, Françoise me diría: 'Mire, está todo apolillado, iqué desgracia! Este trozo de página ya solo es un encaje', y, tras examinarla como un sastre, añadiría: 'No creo que pueda repararlo, está perdido. ¡Qué pena! A lo mejor eran sus mejores ideas. Como dicen en Combray, no hay peleteros más expertos que las polillas. Siempre eligen las mejores telas"'65.

61 Ibid.

62 Ibid.

63 Ibid., p. 38.

64 Proust, M., El tiempo recobrado, Bogotá: Random House Mondadori, 2010, p. 366.

65 Ibid., p. 367. 
En busca del tiempo perdido se trata de una novela que se funda en la creación de un narrador particular: el insomne, que permite al escritor "introducir, al hilo de sus recuerdos, toda una serie de reflexiones que no hubieran podido entrar en una novela clásica"66. El narrador insomne se encuentra en un estado intermedio, entre la vigilia y el sueño, que lo acerca a las profundidades del interior: un estado que luego se transforma en una hipersensibilidad al entorno inmediato, a las luces, sombras, ruidos y silencios, pero también a las palpitaciones interiores, a las imágenes, palabras, sensaciones, pensamientos y sentimientos que afloran con una presencia ineludible en la noche destinada a un sueño que no puede alcanzarse. Proust comienza la primera parte de Por el camino de Swann con la voz del narrador en primera persona: "Mucho tiempo he estado acostándome temprano. A veces apenas había apagado la bujía, se cerraban mis ojos tan pronto que ni tiempo tenía para decirme: 'Ya me duermo'. Y media hora después me despertaba la idea de que ya era hora de ir a buscar el sueño; quería dejar el libro, que se me figuraba tener aun entre las manos, y apagar de un soplo la luz"67. Así se abre un tiempo que se distingue del ordinario, un tiempo subjetivo que se desprende, alejándose, del tiempo cuantificado y medido del tiempo del reloj. El insomne experimenta una contigüidad fantasmagórica entre la vigila y el sueño, que esfuma las fronteras entre lo que ocurre en el fondo onírico y lo que emerge en una vigilia interrumpida y quebradiza. Los pensamientos fluyen atravesando los dos mundos, explorando diferentes terrenos de la subjetividad: "Durante mi sueño no había cesado de reflexionar sobre lo recién leído, pero era muy particular el tono que tomaban esas reflexiones, porque me parecía que pasaba a convertirme en el tema de la obra, en una iglesia, en un cuarteto, en la rivalidad de Francisco I y Carlos V"68. "Esta figuración -continúa el narrador- me duraba aun unos segundos después de haberme despertado, aceptada por la razón, gravitando sobre los ojos que aún no percibian que la vela ya se había apagado"69.

Por último, se trata de una novela guiada por una "voluntad restauradora"70 que llevó a Proust a intentar recuperar no solo "el tiempo perdido" sino también la narración en tanto experiencia. En 1936, en el ensayo "El narrador. Reflexiones sobre la obra de Nikólai Leskov", Benjamin anuncia

\footnotetext{
66 Proust, M., Contra Sainte-Beuve: Recuerdo de una mañana, p. 22.

67 Proust, M., En busca del tiempo perdido. Por el camino de Swann, p. 9.

68 Ibid.

69 Ibid.

70 Benjamin, W., Baudelaire, p. 191.
} 
el declive del arte de narrar, intimamente ligado - desde la perspectiva del pensador alemán- a la decadencia del valor de la experiencia. Encuentra que, en su tiempo, resultaba cada vez más lejana la facultad de intercambiar experiencias $^{71}$. La guerra de trincheras, exponente de la capacidad destructiva de la modernidad, radicalizaba el shock que Edgar Allan Poe y Charles Baudelaire habían incorporado a la literatura en el siglo XIX. El silencio después de la traumática experiencia de la Gran Guerra atrofiaba la extensa tradición de la narración. Se trataba de una nueva pobreza, inmaterial, subjetiva y cultural, propia de la modernidad en el desarrollo de sus contradicciones más profundas. Después de plantear las condiciones pre-modernas para la experiencia de la narración, Benjamin establece una conexión entre "el ocaso de la narración" y el desarrollo de la novela, género literario que se desliga de la tradición oral $\mathrm{y}$, por ende, del género épico ${ }^{72}$. Esta idea benjaminiana no resultaba, para 1936, tan novedosa: ya en el siglo XIX y en pleno apogeo del capitalismo y la modernidad cultural con la cual éste se entrelazaba fantasmagóricamente, el músico compositor Richard Wagner asociaba la novela con una etapa burguesa, moderna, caracterizada por el aislamiento del individuo en la creación y en la recepción del $\operatorname{arte}^{73}$. Hay una ruptura en la transmisión de la experiencia, en la tradición oral de la poética. Dice Benjamin: "El narrador cuenta lo que es producto de la experiencia, ya sea la suya propia o una comunicada. Y a su vez hace la experiencia de quienes escuchan su historia. El novelista, en cambio, se confina en su aislamiento. La novela se ha elaborado en las profundidades del individuo solitario... Escribir una novela es destacar por todos los medios lo que hay de inconmensurable en la vida" ${ }^{4}$. Pero Marcel Proust, desde la intima singularidad de su experiencia, alcanza -y aquí la inteligencia viene a asumir su papel- a condensar, en el concepto de "memoria involuntaria", un fenómeno compartido por toda la especie humana, trascendiendo lo que "hay de inconmensurable en la vida".

\footnotetext{
${ }^{71}$ Benjamin, W. Escritos franceses, p. 239.

72 Ibid., p. 243.

${ }^{73}$ Wagner distinguía tres estadios históricos: la antigüedad clásica (que entendía como "estadio natural"), la modernidad (que se corresponde con el desarrollo de la sociedad burguesa, y que definía como "estadio cultural") y, por último, el estadio de la humanidad liberada y unida en la fraternidad universal. Wagner identificaba cada estadio con una forma de arte: la antigüedad con la tragedia griega, la modernidad con la novela y la liberación humana con el drama. Mientras la lírica se dirige a las emociones en el estadio natural y la novela al intelecto en el estadio cultural, el drama debía orientarse a cargar de emoción el intelecto (González, B., en: Wagner, R. Ópera y drama, Madrid: Akal, p. 15).

${ }^{74}$ Benjamin, W. Escritos franceses, p. 243.
} 


\section{Las auráticas imágenes de la memoria involuntaria}

Walter Benjamin, en La obra de arte en la época de su reproductibilidad técnica (1936) y en Sobre algunos motivos en Baudelaire (1939), propone la noción de aura y la explora prismáticamente. En otro artículo abordaremos las diferentes dimensiones del fenómeno aurático definido y estudiado por Benjamin, planteando asociaciones con ideas del campo psicoanalítico, pero ahora recogeremos solo algunos elementos que nos permiten iniciar un camino de comprensión del carácter de las imágenes de la memoria involuntaria.

Estos elementos que pondremos de relieve los encontramos esbozados en dos definiciones de aura que se corresponden con los dos textos benjaminianos que mencionamos antes. La primera definición de este concepto es la que nace del análisis de la experiencia con el arte en la modernidad, con la irrupción de las tecnologías que permiten la reproducción mecánica de la imagen: la fotografia y el cine. Benjamin diagnostica, tres años después de "Experiencia y pobreza" -texto en el que anuncia la caída del valor de la experiencia tras la Primera Guerra mundial-, el derrumbe del aura. La reproducción de la imagen determina la pérdida de la unicidad, y es en la unicidad que radica la autenticidad, cualidad que a su vez remite a la originalidad. He aquí una primera forma de definir la noción de aura como una cualidad del objeto de la mirada. Destruir el aura de un objeto implica "privarlo de su halo" uniformando, en la reproducción, lo que antes era único e irrepetible ${ }^{75}$. La reproducción mecánica, que permite la repetición y el desplazamiento, anula "su existencia única en el lugar donde se encuentra"76. Este fenómeno de la decadencia del aura se explica no solo por las transformaciones tecnológicas, sino también por la irrupción de las masas, que -como dice Benjamin- reclaman que el mundo les sea más accesible, y pretenden "tomar posesión inmediata del objeto en la imagen" 77.

Esta primera aproximación al concepto de aura, que implica pensar en una cualidad objetiva, se complejiza cuando Benjamin explicita la pregunta y propone una respuesta que nos lleva a pensar en el aura como una forma de experiencia estética, una relación entre sujeto y objeto mediada por la mirada, un retorno a los orígenes en el ejercicio de contemplación del paisaje natural: “¿Qué es, en definitiva, el aura? Una singular trama de tiempo y espacio: aparición única de una lejanía, por próxima que sea. El hombre que, una

75 Ibid., p. 170.

76 Ibid., p. 66.

77 Ibid., p. 169. 
tarde de verano, se abandona a seguir con su mirada el perfil de un horizonte montañoso o la línea de una rama que alarga su sombra hacia él, ese hombre respira el aura de esas montañas, de esa rama"78. El aura puede entenderse aquí como una cualidad que el sujeto percibe en el objeto de su mirada, pero esa cualidad es, a la vez, producto de una relación entre la profundidad del tiempo inscrito en el objeto y la actualidad de su aparición ante el sujeto. La profundidad del tiempo, que obra una distancia entre el objeto y el sujeto de la mirada, se precipita en un instante único y extraordinario (la trama actual de tiempo y espacio) que puede pensarse como el tiempo pleno de la experiencia y la iluminación profana (pensando el fenómeno aurático más allá de una posible asunción romántica).

Se trata de una aparición, de algo que -como en el caso de las imágenes de la memoria involuntaria- se presenta a un sujeto en pasión. La pasividad, como en el sueño y la visión, persiste como condición para la revelación para el acceso a imágenes verdaderas. En este caso, no por provenir del fondo inconsciente, ni por ser entendidas como sagradas, sino por ser auténticas y originales. Por otro lado, tanto la aparición en el fenómeno del aura como en el de la memoria involuntaria es irrepetible ${ }^{79}$. Si las imágenes del pasado olvidado que se revelan en el despertar de la memoria involuntaria escapan a la evocación consciente, a la reiteración deseada por un sujeto que quiere apoderarse de esos fragmentos de su pasado, entonces constituyen la "aparición irrepetible de una lejanía”, de algo remoto que nos remite a los orígenes, a una presencia latente y opaca que se manifiesta fulgurante en un momento único y revelador. Así fue para el narrador de En busca del tiempo perdido el encuentro con aquellas imágenes de su infancia y del Combray de ese tiempo lejano. Lo lejano es también, para Benjamin, lo inasequible ${ }^{80}$. Esa inaccesibilidad propia de las imágenes y objetos que, en tiempos pre-modernos, como plantea Benjamin, pertenecían a la sacralidad -fundando su valor en el ritual y no en la exhibición, como ocurre en el arte moderno- está presente en la literatura de Proust, en la relación entre el sujeto escribiente y las imágenes-relámpagos que le arroja la memoria involuntaria.

Georges Didi-Huberman, en Lo que vemos, lo que nos mira, propone pensar el aura como "un espaciamiento obrado y originario del mirante y

\footnotetext{
${ }^{78}$ Ibid.

79 Proust, M., La memoria involuntaria, p. 92.

${ }^{80}$ Benjamin, W., Baudelaire, p. 199.
} 
el mirado, del mirante por el mirado"81, un "paradigma visual"82 que implica tres poderes en actividad: el "poder de la distancia", el "poder de la mirada" y el "poder de la memoria"83. El poder de la distancia, en el acontecimiento del aura, en la aparición, encierra una relación dialéctica entre lejanía y cercanía. Como plantea Didi-Huberman, "si la lejanía se nos aparece, ¿esta aparición no es ya una manera de acercarse dándose a nuestra vista? Pero ese don de la visibilidad -Benjamin insiste en ello- quedará bajo la autoridad de la lejanía, que no se muestra allí más que para mostrarse distante, todavía y siempre, no importa cuán próxima esté su aparición"84. En la misma proximidad, el objeto aparece lejano, con toda su profundidad, con todo el tiempo en él inscrito. La aparición de las imágenes involuntarias no solo es extraordinaria por ser irrepetible, sino también por hacer próximo lo lejano y lejano lo próximo. Es aquí que podemos encontrar otro elemento relevante para entender el carácter de las imágenes de la memoria involuntaria, que se asemejan a las oníricas en este punto: la extrañeza. Así como Freud afirmaba que las imágenes oníricas se le presentaban al sujeto soñante como ajenas, las de la memoria involuntaria se presentan con la impronta del olvido, que hace que estas se hagan visibles únicamente como distantes, lejanas o inaccesibles. Georges Didi-Huberman define el aura como un acontecimiento único y extraño, y al objeto aurático como aquel que se mueve ante el sujeto en un ida y vuelta incesante, presentándose lejano y cercano, como el "indicio de una pérdida a la que sostiene, a la que obra visualmente" 85 . Las imágenes de la memoria involuntaria pueden pensarse como auráticas también en este sentido, como "obras de la ausencia"86, como indicios de una pérdida, de un olvido, de algo que -en ese estado- pervive en el interior oculto que resulta tan propio y extraño a la vez. Las imágenes suscitadas por las sensaciones que se despiertan al saborear la magdalena con el té se presentan, tomando las palabras de Didi-Huberman para referirse a las imágenes auráticas, como "lo que volvería a nosotros de lejos, nos incumbiría, nos miraria y se nos escaparía a la vez" ${ }^{27}$.

Los otros dos poderes a los que se refiere Didi-Huberman para explicar el fenómeno aurático, el de la mirada y el de la memoria, pueden pensarse

81 Didi-Huberman, G., Lo que vemos, lo que nos mira, Buenos Aires: Manantial, 2014, p. 93.

82 Ibid., p. 94.

83 Ibid., pp. 93-95.

84 Ibid., p. 94.

85 Ibid.

86 Ibid.

87 Ibid. 
a partir de la relectura de "Sobre algunos motivos en Baudelaire" (1939). Se trata de un segundo momento en el que Benjamin vuelve al concepto de aura en el marco de sus investigaciones sobre Baudelaire, la modernidad, la poesía y el spleen (aspectos que hemos presentado en el primer apartado). Aquí aparece el problema del derrumbe del aura en relación con una transformación de las formas de experiencia (en las urbes de la modernidad), de percepción (a partir de la tecnología moderna) y de recepción del arte (en un contexto social en el que las masas se transforman en el sujeto colectivo moderno por antonomasia). $\mathrm{El}$ concepto de memoria involuntaria es abordado en este mismo artículo, en una relación de correspondencia entre el poeta del siglo XIX y Marcel Proust. En este marco, Benjamin piensa el aura como una experiencia de la mirada y de la memoria. Advertir el aura de una cosa, acaba diciendo Benjamin en esta segunda definición del concepto, significa dotarla de la capacidad de alzar la mirada ${ }^{88}$.

En la traducción al francés que realiza Benjamin de un resumen alemán de su texto ${ }^{89}$, plantea una asociación entre el Ideal en la obra de Baudelaire, y la memoria involuntaria descubierta por Proust: "Frente al Spleen, la obra baudeleriana evoca el Ideal. El Ideal es la Memoria involuntaria, iniciadora de correspondencias. Depositario de las imágenes de una vida anterior, el Ideal sería el supremo consuelo sino pusiera en jaque la 'belleza moderna', que es esencialmente esplinética. Los recuerdos más o menos claros que impregnan cada imagen que surge del fondo de la memoria involuntaria pueden considerarse como su 'aura'. Apoderarse del aura de una cosa quiere decir: investirla con el poder de alzar la mirada"90.

El poder de la mirada al que se refiere Didi-Huberman es el que el mirante le asigna al objeto de su mirada. La experiencia del aura, dice Benjamin, radica en la transferencia de una reacción normal en la sociedad humana, a la relación del humano con los objetos inanimados o los elementos de la naturaleza ${ }^{91}$. Podríamos decir aquí, si nos enfocamos en la aurática experiencia de la memoria involuntaria, que se trata de un fenómeno por el cual la relación entre el sujeto y las imágenes de lo que se hallaba olvidado, perdido, implica un proceso de

\footnotetext{
88 Benjamin, W., Baudelaire, p. 199.

89 "Über einige Motive bei Baudelaire", publicado por Zeitschrift für Sozialforschung, 8, 19391940, pp. 50-89. "Los editores alemanes atribuyen ese resumen a la escritura de Benjamin, sin poder dar pruebas formales que lo confirmen" (Benjamin, W. Escritos franceses, p. 268). Aquí, el editor de Escritos franceses se refiere a Rolf Tiedemann, Hermann Schweppenhäuser, Hella Tiedemann-Bartels y Tillman Rexroth.

90 Benjamin, W., Escritos franceses, p. 282.

91 Benjamin, W., Baudelaire, pp. 198-199.
} 
subjetivación que se produce a partir de la visibilización de una distancia que se pliega, que se hace próxima, que ubica al sujeto consciente en una posición de extrañeza en relación con las imágenes de su propia interioridad. Esas imágenes, "indices de lo perdido", interpelan al sujeto consciente devolviéndole una mirada que puede ser inquietante. Ese componente inquietante puede vincularse a lo que Didi-Huberman denominó "poder de la memoria”, que se localiza en esa distancia "que nos mira y nos toca"92. Es la memoria involuntaria, de la que surge -dice Benjamin- un conjunto de imágenes que se arremolinan en torno al objeto sensible que la despierta constituyendo su aura ${ }^{93}$. Las imágenes de la memoria involuntaria son "obras de lo inconsciente"94, componen la "visualidad aurática" en la que "todos los tiempos están trenzados, puestos en juego y desbaratados, contradichos y sobredimensionados"95 como en el sueño.

Hasta aquí hemos presentado un análisis del fenómeno de la memoria involuntaria y de su descubrimiento por parte de Marcel Proust. En el ejercicio escritural que acoge -radicalmente- su tratamiento, se manifiesta -mediante una visualidad aurática- la heterogeneidad temporal propia del inconsciente que Freud se propuso comprender. Encontramos que, en el trabajo de Proust, se expresa una inquietud propia de los artistas e intelectuales críticos de principios de siglo XX, que en plena crisis de la modernidad repensaron las formas de entender la historia y la memoria cuestionando la concepción lineal y homogénea del tiempo. Situamos a Marcel Proust y su descubrimiento poético de la memoria involuntaria en un tiempo histórico, cultural e intelectual impuro y particularmente lúcido: el que Theodor Adorno nombró como Ilustración oscura. Proust participó de este espíritu epistemológico junto con Walter Benjamin, Sigmund Freud, Carl G. Jung, Richard Semon, André Breton, Max Ernst, Howard Carter, James Joyce, Aby Warburg, entre otros. Los inicios del siglo $\mathrm{XX}$, que se forjaron entre las luces tenues y débiles de una civilización en crisis y los fuegos ensordecedores de la guerra, significaron -para algunos artistas e intelectuales- la necesidad de emprender un giro al interior del tiempo, un reencuentro con tradiciones de creación y pensamiento olvidadas, sepultadas por la razón positivista y la ideología del progreso. Estos autores fraguaron una ilustración que no temió a lo oscuro, oculto, extraño o inquietante.

\footnotetext{
92 Didi-Huberman, G., Lo que vemos, lo que nos mira, p. 95.

93 Benjamin, W., Baudelaire, p. 196.

94 Didi-Huberman, G., Lo que vemos, lo que nos mira, p. 95.

95 Ibid.
} 
Desde aquella actualidad crítica, Proust emprendió una búsqueda del tiempo perdido, creando -en el contexto de la esplinética modernidad en crisis- una vía artificial y artística para la vita contemplativa. Poéticamente en la creación literaria y en la construcción conceptual-, Proust descubrió la memoria involuntaria (como fenómeno, como experiencia). Enlazando la novela proustiana con algunos aportes de Sigmund Freud y Theodor Reik, podemos comprender la memoria involuntaria como un fenómeno psíquico y cultural que expresa la tensión entre la consciencia y el inconsciente, el recuerdo y el olvido, la vivencia y la experiencia, la voluntad y lo involuntario, la acción y la pasión. En sintonía con los psicoanalistas, pero también con los surrealistas, Proust se interesó por la dimensión subjetiva que escapa a la voluntad, la razón o la consciencia. Encontró que la revelación de lo olvidado -que está presente de modo latente-, es posible a partir de sensaciones que despiertan una memoria sensible y profunda que se mueve más allá de la inteligencia. Si pensamos el fenómeno desde los esbozos de Benjamin para una teoría del conocimiento, podemos plantear que el tiempo recuperado se hace cognoscible a modo de relámpago en un acontecimiento de iluminación profana que aclara -a veces de manera perturbadora- la actualidad del sujeto. En Proust, la cognoscibilidad que adquiere el pasado inaccesible hasta entonces, da lugar a la poiesis desde un interior que empieza a ser descubierto.

Mediante la comparación con el fenómeno de la memoria onírica -y las investigaciones psicoanalíticas sobre la interpretación de los sueños- y la experiencia visionaria antigua y medieval -localizada en una tradición mística y religiosa que fue secularmente recuperada por los surrealistas-, desarrollamos el análisis de las condiciones subjetivas para la revelación de las imágenes verdaderas (las que vienen del interior-inconsciente y las que vienen de dios, según la concepción religiosa). La condición de pasividad propia de la tradición visionaria, apropiada por Breton y Ernst, nos permite vislumbrar, en el caso de la memoria involuntaria -en la que, finalmente, situamos a la memoria onírica-, una relación de alteridad del sujeto (en tanto constituido por el tándem freudiano percepción-consciencia) con el inconsciente, cuyas manifestaciones parecen ser ajenas al no ser productos de la conciencia y la racionalidad, generando un extrañamiento en el sujeto con respecto a su propia interioridad profunda y oculta.

Este será el punto de partida para una próxima investigación sobre la inquietante extrañeza suscitada por imágenes mnémicas, interiores o auráticas. El concepto benjaminiano de aura, empleado en el último apartado de este 
artículo, junto con las nociones psicoanalíticas de lo siniestro y lo fantasmático, nos permitirán indagar en la dialéctica entre distancia y cercanía, lo propio y lo extraño, el olvido y la memoria.

Recibido: $10 / 04 / 2017$

Aceptado: $13 / 04 / 2018$

\section{Bibliografia}

Agamben, G., Profanaciones. Buenos Aires: Adriana Hidalgo editora, 2005.

Baudelaire, C., El pintor de la vida moderna. Buenos Aires: Taurus, 2014.

Baudelaire, C., Poesía completa. Barcelona: Ediciones 29, 1999.

Benjamin, W. Discursos interrumpidos I. Filosofia del arte y de la historia. Buenos Aires: Taurus, 1989.

Benjamin, W., Escritos franceses, Buenos Aires: Amorrortu, 2012.

Benjamin, W., El libro de los pasajes. Madrid: Akal, 2013.

Benjamin, W., Baudelaire, Madrid: Abada editores, 2014.

Bergson, H., Memoria y vida. Madrid: Alianza, 1977.

Breton, A. "Manifiesto surrealista" en Calvo Serraller, F., Marchán Fiz, S., González, A. Escritos de arte de vanguardia. 1900/1945. Madrid: Istmo-Akal ediciones, 2009.

Cirlot, V., La visión abierta. Del mito del Grial al surrealismo, Madrid: Siruela, 2010.

Cuesta Abad, J.M., "Futuro del surrealismo" en: Becerra, E. (ed.), El surrealismo y sus derivas: visiones, declives y retornos, Madrid: Abada Editores, 2013.

Deleuze, G., Cine II: los signos del movimiento y el tiempo, Buenos Aires: Cactus, 2014. Didi-Huberman, G. Lo que vemos, lo que nos mira. Buenos Aires: Manantial, 2014.

Freud, S., Obras completas. IV. La interpretación de los sueños, Buenos Aires: Amorrortu, 2012.

Freud, S., Obras completas. V. La interpretación de los sueños (segunda parte). Sobre el sueño. Buenos Aires: Amorrortu, 2012.

Freud, S., Obras completas. VI. Psicopatología de la vida cotidiana, Buenos Aires: Amorrortu, 2012.

Hobsbawm, E. Historia del siglo XX. Buenos Aires: Crítica, 1998.

Le Goff, J. La civilización del Occidente medieval. Barcelona: Paidós, 1999.

Proust, M., En busca del tiempo perdido. Por el camino de Swann, Buenos Aires: CS Ediciones, 2006.

Proust, M., Contra Sainte-Beuve: Recuerdo de una mañana. Madrid: Alianza Editorial, 2010.

Proust, M., El tiempo recobrado. Bogotá: Random House Mondadori, 2010.

Ricoeur, P., La memoria, la historia, el olvido. Buenos Aires: Fondo de Cultura Económica, 2013.

San Agustin, Confesiones. México: Porrúa, 2015.

Wagner, R. Ópera y drama. Madrid: Akal, 2013.

ARETÉ Revista de Filosofía, vol. XXX, N², 2018 / ISSN 1016-913X 